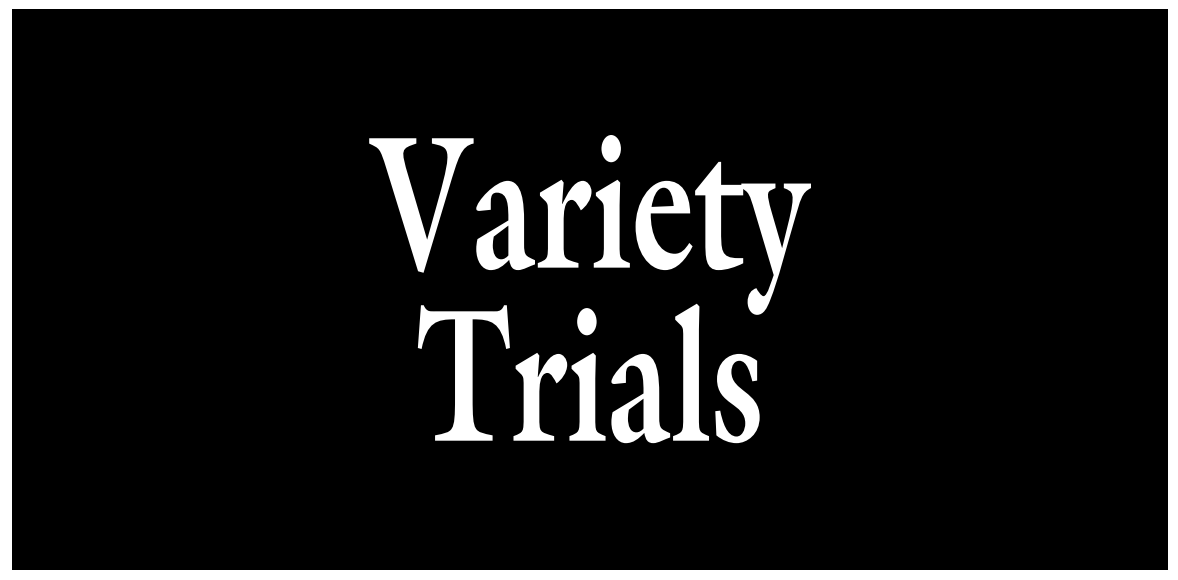

\section{Ornamental Jujube Cultivar Evaluation in the Southwestern United States}

\author{
Shengrui $\mathrm{Yao}^{1,2,3}$ and Robert Heyduck ${ }^{2}$
}

AdDitional INDEX wORDs. Ziziphus jujuba, edible landscape, winter aesthetic

Summary. All jujube (Ziziphus jujuba) cultivars can be used as fruit trees and in landscaping, but there are four striking ornamental cultivars in our collection: Dragon, Mushroom, So, and Teapot. These cultivars are decorative and can be used for fruit, tree shape, or both as edible landscape plants. We evaluated these four ornamental jujube cultivars in central and northern New Mexico. All four cultivars grew and produced well but performed differently. 'So', imported from China in 1914, was a productive and contoured cultivar with medium-sized, sweet/tart fruit and bushy trees, with a decorative tree shape in winter. 'Dragon', a recent import from China, was the most dwarf cultivar tested, with small fruit and gnarled trees, and suitable for four-season ornamental use in landscapes. 'Mushroom', another recent import from China, had the most decorative fruit shape among the four cultivars tested, with vigorous and productive plants. 'Teapot', also a recent import from China, had irregular fruit shapes and vigorous and productive plants. All four cultivars were good edible landscape plants depending on customers' preferences and space availability/limitation.

$\mathrm{J}$ ujube (Ziziphus jujuba) originated in China and was imported to the United States beginning in 1908. There are over 800 jujube cultivars in China, while only 70-80

We acknowledge the critical internal review from Steve Guldan and Frank Sholedice III at New Mexico State University. We would like to thank Dr. Wang from Beijing Forestry Institute for collecting jujube scionwood in China. We also thank David Archuleta, David Salazar, and Margarito Hernandez at NMSU's Sustainable Agriculture Science Center at Alcalde for their technical support, and Tom Place, Dennis Price, and all the field crew for taking care of the cultivar trial at the NMSU Agricultural Science Center at Los Lunas.

This project was partially supported by a Specialty Crop Block Grant through the New Mexico Department of Agriculture, Hatch funds from the USDA National Institute of Food and Agriculture, and the New Mexico Agricultural Experiment Station.

${ }^{1}$ Department of Plant and Environmental Sciences, New Mexico State University, Alcalde, NM 87511

${ }^{2}$ Sustainable Agriculture Science Center at Alcalde, New Mexico State University, Alcalde, NM 87511

${ }^{3}$ Corresponding author. E-mail: yaos@nmsu.edu

https://doi.org/10.21273/HORTTECH04073-18 are available in the United States, and most of these were imported from China (Liu and Wang, 2009; Yao, 2013a). Most of these cultivars are grown for fresh eating, drying, or processing. Jujube fruits are nutritious, with high amounts of vitamin $\mathrm{C}$, cyclic adenosine monophosphate, dietary fiber, minerals, and antioxidants (Huang et al., 2017; Liu and Wang, 2009; Zhao et al., 2017). There are some cultivars well known for their ornamental properties, such as unique fruit shape, fruit color change, or tree shape (Liu and Wang, 2009), that are also suitable as edible landscape plants. Using edibles in landscapes can enhance a garden by providing ornamentals with additional health, aesthetic, and economic benefits (Creasy, 2009). These ornamental jujube cultivars may not have the best fruit quality or the highest yield, but they can provide more enjoyment than regular jujube cultivars or common ornamental trees.

Cultivar So was imported by Frank N. Meyer in 1914 (accession \#37484), who described it as "a variety of jujube of very gnarled and zigzag growth. The fruits are said to be round, medium size, shining brown-red and of sweet taste" (Taylor, 1917). The U.S. Department of Agriculture (USDA) Chico Plant Introduction Station (Chico, CA) did not recommend 'So' in the 1920s (Thomas, 1927), but 'So' was used for breeding purposes (Ackerman, 1961). An open-pollinated seedling of 'So', with flat fruit shaped like a mini donut, was named 'Chico' to commemorate the USDA Chico Plant Introduction Station (Thomson, 1971). Cultivar Dragon, also called Longzao, was named from its tree shape with twisted branches, while 'Mushroom' and 'Teapot' were named from their fruit shapes (Guo and Shan, 2010; Liu and Wang, 2009).

Jujube research and cultivar trials are limited in the United States. We established jujube cultivar trials in both central [Los Lunas, NM (zone $7 \mathrm{a})$ ] and northern [Alcalde, NM (zone 6a)] New Mexico in 2015. The objective of this study was to evaluate the four ornamental cultivars (Dragon, Mushroom, So, and Teapot) and assess their potential as edible landscape trees.

\section{Materials and methods}

In 2011 , over 30 cultivars were imported into the United States directly from China as scionwood.

\begin{tabular}{llll}
\hline $\begin{array}{l}\text { Units } \\
\text { To convert U.S. to SI, } \\
\text { multiply by }\end{array}$ & U.S. unit & SI unit & $\begin{array}{l}\text { To convert SI to U.S., } \\
\text { multiply by }\end{array}$ \\
\hline 0.3048 & $\mathrm{ft}$ & $\mathrm{m}$ & 3.2808 \\
2.54 & inch $(\mathrm{es})$ & $\mathrm{cm}$ & 0.3937 \\
25.4 & inch $(\mathrm{es})$ & $\mathrm{mm}$ & 0.0394 \\
0.4536 & $\mathrm{lb}$ & $\mathrm{kg}$ & 2.2046 \\
1.1209 & $\mathrm{lb} / \mathrm{acre}$ & $\mathrm{kg} \cdot \mathrm{ha}^{-1}$ & 0.8922 \\
28.3495 & $\mathrm{oz}$ & $\mathrm{g}$ & 0.0353 \\
0.1 & $\mathrm{ppm}$ & $\mathrm{mg} / 100 \mathrm{~g}$ & 10
\end{tabular}


Table 1. Jujube growing and fruiting habits of four ornamental cultivars at Alcalde, NM (n=20).

\begin{tabular}{|c|c|c|c|c|c|c|}
\hline Cultivar & $\begin{array}{c}\text { Flower diam } \\
{[\text { mean } \pm \text { SE }(\mathrm{mm})]^{\mathrm{z}}}\end{array}$ & $\begin{array}{c}\text { Blooming } \\
\text { type }^{\mathrm{y}}\end{array}$ & $\begin{array}{c}\text { Flowers } \\
(\text { no./node })^{x}\end{array}$ & $\begin{array}{c}\text { Branchlet } \\
\text { length } \\
{[\text { mean } \pm \text { SE }(\mathrm{cm})]^{\mathrm{z}}}\end{array}$ & $\begin{array}{c}\text { Leaves } \\
\text { (no./branchlet) }\end{array}$ & $\begin{array}{c}\text { Leaf size } \\
{[\text { length } \times \text { width }(\mathrm{cm})]}\end{array}$ \\
\hline Dragon & $7.0 \pm 0.18$ & PM & $3-6$ & $17.1 \pm 0.75$ & 11.6 & $5.2 \times 2.4$ \\
\hline So & $6.0 \pm 0.05$ & $\mathrm{AM}$ & $3-5$ & $14.6 \pm 0.82$ & 12.2 & $4.4 \times 2.1$ \\
\hline Teapot & $6.4 \pm 0.08$ & PM & $3-7$ & $17.4 \pm 0.31$ & 10.2 & $6.7 \times 3.4$ \\
\hline
\end{tabular}

${ }^{\mathrm{z}} 1 \mathrm{~mm}=0.0394$ inch, $1 \mathrm{~cm}=0.3937$ inch.

${ }^{\mathrm{y}} \mathrm{AM}=$ morning blooming type, $\mathrm{PM}=$ afternoon blooming type.

${ }^{\mathrm{x}}$ Referring to the middle section of the branchlets, not the base or tip section.

'Dragon', 'Mushroom', and 'Teapot' were part of this importation (Yao, 2013a). Cultivars including So were purchased from the late Roger Meyer's family nursery in California in 2011. The scionwood was first grafted onto wild jujube (Ziziphus spinosa) sucker rootstocks, which had been planted in 2010 at the New Mexico State University (NMSU) Sustainable Agriculture Science Center at Alcalde. Each cultivar was grafted to another one or two wild jujube seedlings at Alcalde in 2012. Those 2011 and 2012 grafted trees were in the germplasm repository area at a density of $4 \times 6 \mathrm{ft}$, and were used for the jujube growth and flowering habit study. Twenty branchlets from branches 2 years or older were sampled in mid-June 2013 and 2014 for branchlet length, leaf number, leaf size and flower bud number at each node. Flower diameter was measured across sepals (not the diameter of petals like other fruit species), and an average of 20 fully bloomed flowers for each cultivar was recorded. Flower blooming time (when the sepals start to separate) was observed several times from June to July during 2012-14. Leaf size (length $\times$ width) was taken from the average of 20 leaves with one or two from the middle part of each branchlet from each cultivar.

Trees were propagated/grafted onto wild jujube seedlings at Alcalde in 2014, and cultivar trials with over 35 cultivars at each site were established at the NMSU Agricultural Science Centers at Los Lunas and Alcalde in Apr. 2015 with a randomized complete block design of two replicates and two trees per block per cultivar. The planting density was $8 \times$ $12 \mathrm{ft}$ at Alcalde and $8 \times 15 \mathrm{ft}$ at Los Lunas. Trees were fertilized once each year after leafing out and before full bloom at a rate of $40 \mathrm{lb} /$ acre nitrogen
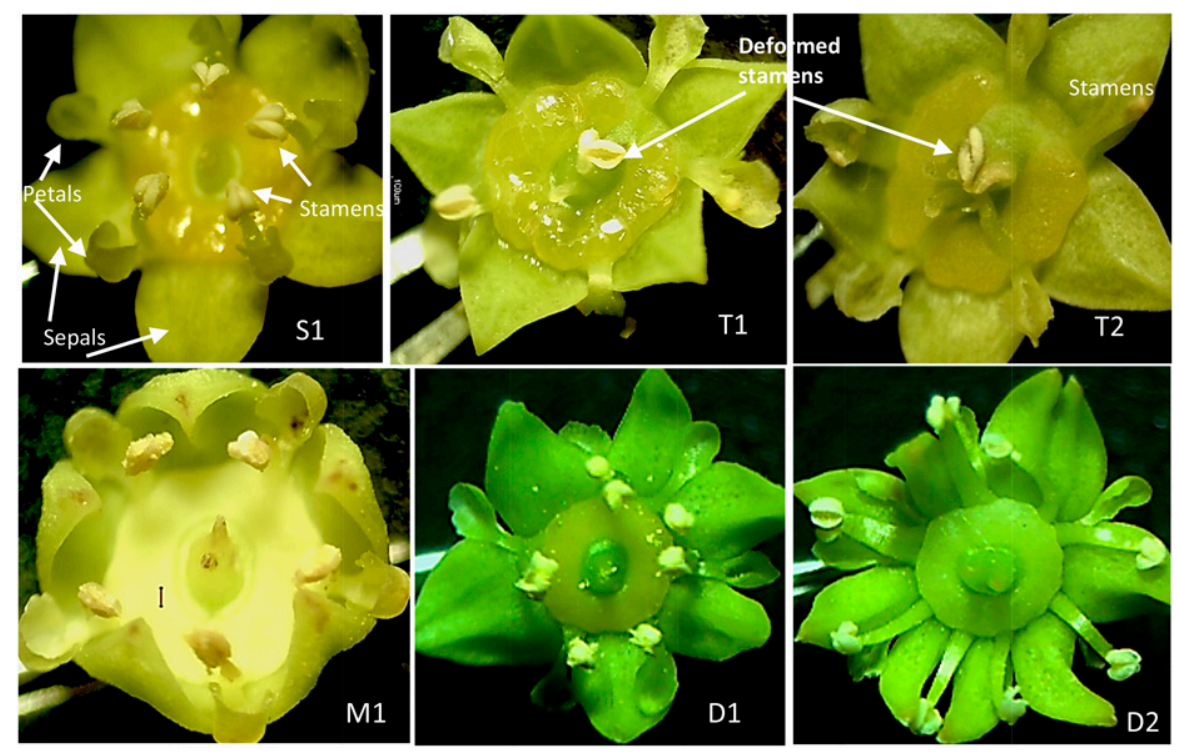

Fig. 1. Jujube flowers of four ornamental jujube cultivars. Flowers of 'So' represented normal jujube flowers with five sepals, five petals, and five stamens (S1); flowers of 'Mushroom' had five sepals/petals/stamens, but kept the cupshape even after blooming instead of flat or down curled sepals/petals/stamens like regular jujube cultivars (MI); flowers of 'Dragon' had five to eight sepals / petals/stamens (D1 and D2); flowers of 'Teapot' had five sepals/petals but with one to five deformed stamens (T1 and T2).

Table 2. Tree size of 3-year-old ornamental jujube cultivars at Alcalde, NM (AL) and Los Lunas, NM (LL) $(n=4)$.

\begin{tabular}{|c|c|c|c|c|c|}
\hline \multirow[b]{2}{*}{ Cultivar } & \multicolumn{2}{|c|}{ Tree ht $(\mathrm{ft})^{\mathrm{z}}$} & \multicolumn{2}{|c|}{ Tree width $(\mathrm{ft})$} & \multirow{2}{*}{$\frac{\text { Tree uprightness }^{y}}{\text { LL }}$} \\
\hline & LL & $\mathrm{AL}$ & LL & $\mathrm{AL}$ & \\
\hline Dragon & $4.3 c^{x}$ & $4.8 \mathrm{c}$ & $2.9 \mathrm{~b}$ & $4.3 \mathrm{~b}$ & 4.0 \\
\hline Mushroom & $11.0 \mathrm{a}$ & $10.9 \mathrm{a}$ & $5.3 \mathrm{ab}$ & $7.3 \mathrm{a}$ & 1.8 \\
\hline So & $9.4 \mathrm{~b}$ & $7.9 \mathrm{~b}$ & $7.1 \mathrm{a}$ & $6.4 \mathrm{a}$ & 4.0 \\
\hline Teapot & $11.2 \mathrm{a}$ & $12.6 \mathrm{a}$ & $5.0 \mathrm{ab}$ & $7.0 \mathrm{a}$ & 2.3 \\
\hline
\end{tabular}

${ }^{2} 1 \mathrm{ft}=0.3048 \mathrm{~m}$

${ }^{\mathrm{y}} 1$ = upright, 2 = more upright than bushy, 3 = more bushy than upright, 4 = bushy.

${ }^{\mathrm{x}}$ Any two means within a column not followed by the same letter are significantly different at $P \leq 0.05$ with Fisher's protected least significant difference procedure.

(urea), $12.9 \mathrm{lb} /$ acre phosphorus (triple super phosphate), and $16.6 \mathrm{lb} /$ acre potassium (potash). Light pruning was conducted annually in late February/early March at each site.

Tree growth and yield data were collected from the cultivar trials at both locations. Tree height, crown width (spread), and uprightness were observed/measured in Mar. 2018. Fruit diameter, length, and yield data were collected in Sept./Oct. 2017. Fruit weight and fruit size were calculated by averaging the measurements of 30 randomly picked fruit. Soluble solids concentration (SSC) was measured from juice extracted out of small pieces of 8-10 fruit with a modified garlic press, 
using a temperature-compensated refractometer (PAL-1; Atago, Bellevue, WA). Fruit vitamin $C$ content was measured by 2,6-dichlorophenolindophenol titration (Bessey, 1933), and titratable acid was determined by titration with $0.01 \mathrm{~N}$ sodium hydroxide in 2017 (Huang et al., 2017).

Most characteristics are descriptive rather than quantitative and presented as mean \pm SE. Tree height, width, and yield data were analyzed with statistical software Statistix (version 9, Analytical Software, Tallahassee, FL).

\section{Results and discussion Growing and fruiting habits}

FLOwER. Flowers of 'So' had five sepals, five petals and five stamens, and their sepals, petals and stamens turned flat or curled downward in the later stage of blooming or after blooming like most other jujube cultivars (Table 1; Fig. 1) (Yao et al., 2015 ). 'Dragon' had relatively larger flowers than others with five to eight sepals and petals, and the sepals were non-uniform in size and shape (Fig. 1). 'Mushroom' had cup-shaped flowers with five sepals and petals. Unlike regular jujube cultivars (Yao et al., 2015), its sepals did not lay flat or turn backward but stayed upright until falling off (Fig. 1). The relatively small diameter of 'Mushroom' flowers was due to its cup-shaped flowers. 'Teapot' flowers had five sepals and petals with one to five deformed stamens, and the stamen number varied from flower to flower (Fig. 1). The number of deformed stamens corresponded to the number of protrusions on its fruit (Yao, 2013b). 'Mushroom' had more flower buds in each node in the middle part of the branchlet than other cultivars (Table 1). Flowers of 'Mushroom' and 'So' were morning blooming type with sepals of flower buds opening in the morning, while 'Dragon' and 'Teapot' were afternoon blooming type with sepals of flower buds cracking open in the afternoon.

BRANCH AND TREE SHAPE. 'So' had smaller leaves and shorter branchlets than the other three cultivars (Table 1). Trees were compact and bushy, with many zigzagged branches and side branches (Table 2; Fig. 2). With its zigzagged structure, main buds of fruiting spurs in dominant locations popped out as branches. 'So' trees looked decorative during

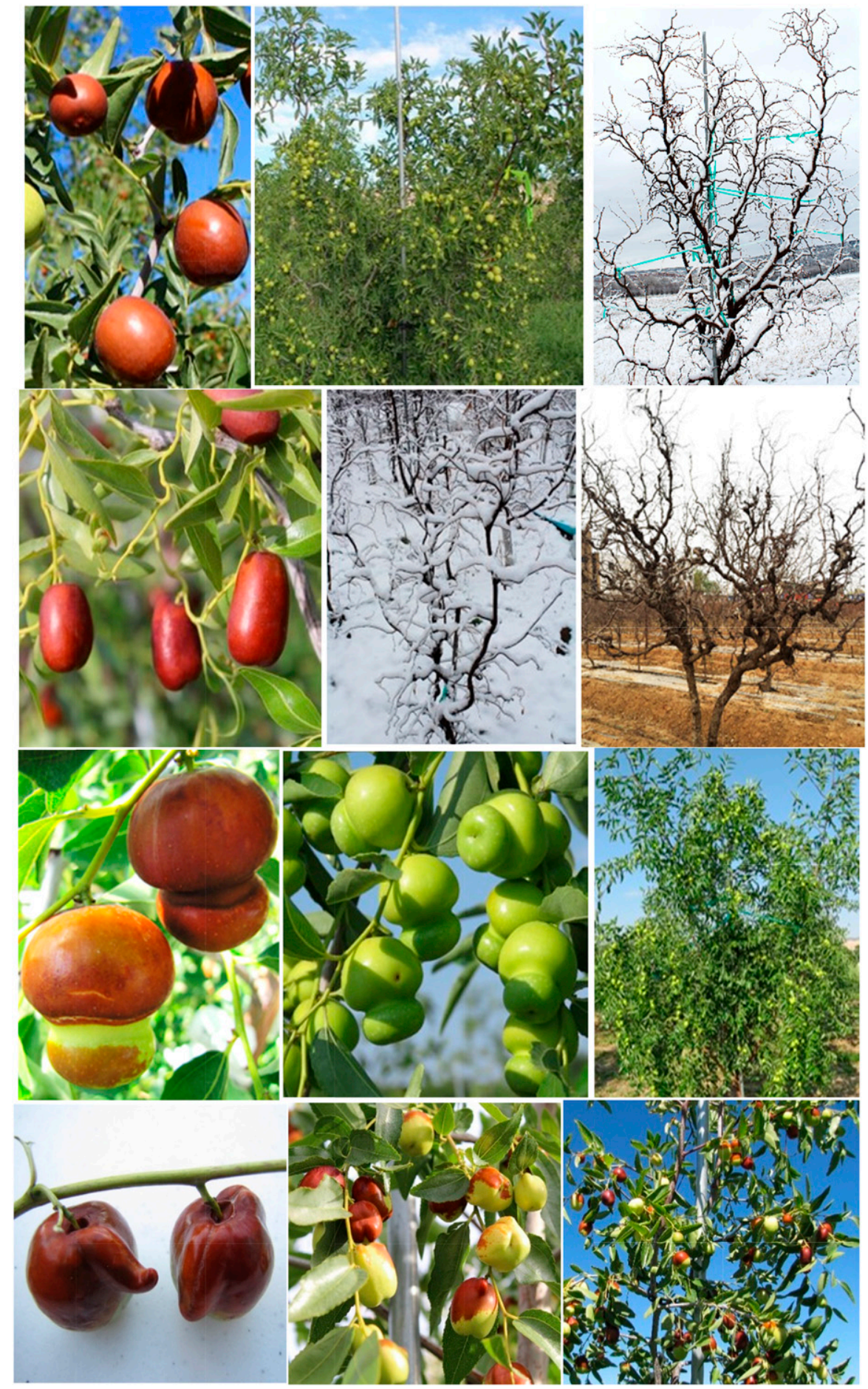

Fig. 2. Ornamental jujube cultivars Dragon, Mushroom, So and Teapot in New Mexico. Row 1: 'So' fruit, fruit on the tree, and 7-year-old tree shape in winter. Row 2: 'Dragon' fruit, 2-year-old tree in winter, and mature tree (mature tree picture was taken in China). Row 3: 'Mushroom' tree and fruit. Row 4: 'Teapot' tree and fruit.

the growing season and in winter, and even more beautiful after snow (Fig. 2).

For 'Dragon', both branchlets and branches were twisted (Fig. 2). 'Dragon' leafed out 1-2 weeks later than most cultivars and were the smallest trees among all cultivars tested in New Mexico (Table 2; Fig. $2)$. A mature tree of 'Dragon' in China was around $6 \mathrm{ft}$ tall (Fig. 2).

'Teapot' and 'Mushroom' trees measured $11-12.6 \mathrm{ft}$ at 3 years old, 'So' trees were 7.9-9.4 ft, and 'Dragon' trees were 4.3-4.8ft (Table 2). 
Table 3. Three-year-old ornamental jujube tree yield and fruit quality data in cultivar trials at Alcalde, NM (AL) and Los Lunas, NM (LL). For fruit size and fruit weight $(n=30)$. Soluble solids content $(S S C)$ and vitamin $C$ content are for reference only.

\begin{tabular}{|c|c|c|c|c|c|c|c|c|c|}
\hline \multirow[b]{2}{*}{ Cultivar } & \multicolumn{2}{|c|}{ Yield $(\mathrm{lb} / \text { tree FW })^{\mathrm{z}}$} & \multicolumn{2}{|c|}{ Fruit wt $(g)^{\mathrm{z}}$} & \multicolumn{2}{|c|}{ Fruit size $[\text { length } \times \text { width }(\mathrm{mm})]^{\mathrm{z}}$} & \multicolumn{2}{|c|}{ SSC (\%) } & \multirow{2}{*}{$\begin{array}{c}\begin{array}{c}\text { Vitamin } \mathrm{C} \\
(\mathrm{mg} / 100 \mathrm{~g} \mathrm{FW})^{\mathrm{z}}\end{array} \\
\mathrm{AL}\end{array}$} \\
\hline & $\mathrm{AL}$ & $\mathrm{LL}$ & $\mathrm{AL}$ & LL & $\mathrm{AL}$ & LL & $\mathrm{AL}$ & $\mathrm{LL}$ & \\
\hline Dragon $^{y}$ & $0.2 c^{x}$ & $0.04 \mathrm{~b}$ & 7.5 & - & $35.7 \times 22.6$ & - & 29.1 & - & 397 \\
\hline Mushroom & $8.0 \mathrm{ab}$ & $4.9 \mathrm{a}$ & 10.9 & 9.5 & $33.1 \times 28.4$ & - & 29.5 & - & 436 \\
\hline So (large fruit) & $3.8 \mathrm{bc}$ & $5.4 \mathrm{a}$ & 11.7 & 11.0 & $29.7 \times 30.2$ & $29.5 \times 29.9$ & 30.0 & 31.2 & 349 \\
\hline So (small fruit) ${ }^{w}$ & & & 4.9 & 5.0 & $20.6 \times 22.2$ & $22.3 \times 22.6$ & 29.8 & 31.2 & \\
\hline
\end{tabular}

${ }^{\mathrm{z}} \mathrm{l} \mathrm{lb}=0.4536 \mathrm{~kg}, \mathrm{lg}=0.0353 \mathrm{oz}, \mathrm{l} \mathrm{mm}=0.0394$ inch; $1 \mathrm{mg} / 100 \mathrm{~g}=10 \mathrm{ppm}$.

'There were not enough 'Dragon' fruit for fruit weight, fruit size and SSC measurement at LL in 2017.

'Any two means within a column not followed by the same letter are significantly different at $P \leq 0.05$ with Fisher's protected least significant difference procedure.

'The small fruit of 'So' were only used for fruit weight, fruit size and SSC measurement. For yield data, all fruit were counted; for vitamin C measurement, the sample was randomly-picked from both large and small fruit.

'Mushroom' and 'Teapot' were vigorous and upright trees, while 'So' and 'Dragon' trees were bushy (Table 2; Fig. 2). 'So' was the most bushy looking tree and 'Dragon' was the most dwarf tree among all 45 cultivars tested at Alcalde and Los Lunas (data not shown).

'So' was imported from China, but was not currently listed in Chinese jujube literature (Guo and Shan, 2010; Liu and Wang, 2009). There were two gnarled and zigzagged cultivars in Chinese literature: 'Longzao' ('Dragon') and 'Dali Longzao'. 'Dali Longzao' has a different fruit shape and size compared with 'Longzao' (Liu and Wang, 2009). Both branches and branchlets of 'Dragon' and 'Dali Longzao' could have straight sections, but they also had hairpin structures or twisted ring structures that make the branches turn $180^{\circ}$ or more. The branch pattern of 'So' was regularly zigzagged, with rare hairpin structure which can be used to identify 'So' and 'Dragon'.

FRUIT. 'So' had round fruit with two general weight and size categories. Larger fruit had an average weight of $11 \mathrm{~g}$ with seeds, while the smaller ones averaged around $5 \mathrm{~g}$ without seeds (Table 3 ). The larger fruit of 'So' were heavier than 'Mushroom', but on average 'Mushroom' fruit were larger than 'So', followed by 'Teapot', and the smallest were the fruit of 'Dragon' (Table 3; Fig. 2). 'Dragon' produced small, columnarshaped fruit weighing $7.5 \mathrm{~g}$ on average (Table 3). 'Mushroom' had uniform and decorative buttonmushroom-shaped fruit (Table 3; Fig. 2). 'Mushroom' kept its fruit shape after drying, and could be used as a dry ornamental together with other dry flowers/plants. The typical fruit of 'Teapot' were miniature teapot-shaped (Fig. 2), but fruit could have zero to five protrusions with various shapes and sizes, and teapotshaped fruit were just a small proportion of all fruit. Yao (2013b) discussed the detailed fruit development of 'Teapot'. Fruit of 'Teapot' matured later than 'So', 'Mushroom', and 'Dragon'.

\section{Fruit quality and productivity}

'Teapot' yielded higher than 'So' and 'Dragon' at Alcalde, while at Los Lunas, 'So', 'Mushroom' and 'Teapot' produced similar yield, all higher than 'Dragon' (Table 3). 'Dragon' was the least productive cultivar in both locations. At Alcalde, 3 -year-old 'Teapot' trees produced an average yield of $10.0 \mathrm{lb} /$ tree, with a maximum of $14.3 \mathrm{lb} /$ tree; 'Mushroom' fruit yield averaged $8.0 \mathrm{lb} /$ tree, with a maximum of $10.9 \mathrm{lb} /$ tree; and 'So' yielded an average of $3.8 \mathrm{lb} /$ tree, with a maximum of $8.6 \mathrm{lb} /$ tree $(\mathrm{Ta}$ ble 3 ). 'Dragon' was a miniature tree with less than $0.3 \mathrm{lb} /$ tree of fruit at Alcalde in 2017. 'So' yielded more at Los Lunas than at Alcalde while other cultivars yielded less at Los Lunas than at Alcalde, which could be related to water stress from mid-August to mid-September due to a broken main irrigation pipeline at Los Lunas in 2017. The higher yield of 'So' at Los Lunas could also be partially due to its bushy growing habits with more branches than other cultivars.

The SSC contents varied from $29 \%$ to $32 \%$ depending on cultivar and location (Table 3). Normally, fruit from Los Lunas had higher SSC than fruit from Alcalde for almost all cultivars, which was possibly due to a longer growing season at Los Lunas than Alcalde (Huang et al., 2017) and we noticed similar trends in these ornamental cultivars (Table $3)$. The fruit vitamin $\mathrm{C}$ contents ranged from 313 to $436 \mathrm{mg} / 100 \mathrm{~g}$ FW (Table 3). 'So' and 'Dragon' had higher titratable acid contents than 'Mushroom' and 'Teapot', and also higher than popular cultivars $\mathrm{Li}$ and Lang (data not shown).

Among these four ornamental cultivars, 'So' had better sweet/tart and juicy fruit than others, while 'Mushroom' had the most decorative fruit both fresh and dried. Fruit of 'So' was good for both fresh eating and drying. Fruit of 'Teapot' was sweet and matured later in the season than others.

\section{Potential as edible landscape plants}

Jujubes are drought-tolerant plants when they are mature. They also have small, shiny leaves without many known pests or diseases in the southwestern United States (Yao, 2013a). They have a 2 -month blooming period that attracts many insects, and function as a sanctuary for beneficial insects (Grasswitz and Yao, 2017; Yao, 2018). All jujube cultivars can be used as edible landscape plants in landscaping or backyards, but the four presented here are more decorative than common jujube cultivars.

With shiny green leaves and green fruit during the growing season, red fruit and yellow leaves in the fall, and gnarled and zigzagged branches/branchlets, both 'So' and 'Dragon' are good backyard trees and excellent landscape plants with edible and nutritious fruit. If there is tall 
space in the landscape, 'Mushroom' is recommended; 'So', with its compact stature compared with 'Mushroom', is recommended for not very tall but wide spaces, while 'Dragon' is a dwarf type suitable for small spaces. All can provide edible fruit. Depending on a customer's preference and space, they can choose suitable cultivars accordingly.

Ornamental jujube cultivars are low-maintenance plants with minimal winter pruning and growing season fertilization and watering. 'Teapot' and 'Mushroom' provide three seasons of decoration, while 'So' and 'Dragon' can be used as year-round ornamentals. We do want to point out that all jujube trees have thorns, especially newly planted young trees, but become less thorny after 3-5 years. Growers should be cautious when handling jujube trees.

\section{Literature cited}

Ackerman, W.L. 1961. Flowering, pollination, self-sterility and seed development of chinese jujube. Proc. Amer. Soc. Hort. Sci. 77:265-269.

Bessey, O. 1933. The distribution of vitamin $\mathrm{C}$ in plant and animal tissues, and its determination. J. Biol. Chem. 103: 687-698.
Creasy, R. 2009. Edible landscaping basics. 20 Apr. 2018 . <http://www. rosalindcreasy.com/edible-landscapingbasics $/>$.

Grasswitz, T. and S. Yao. 2017. Potential value of Ziziphus jujuba Mill. as a dual-purpose insectary plant for smallscale farms. 20 June 2018. <https://esa. confex.com/esa/2017/meetingapp.cgi/ Paper/124308>.

Guo, Y. and G. Shan. 2010. The chinese jujube. Shanghai Scientific Technical Publ., Shanghai, China. (in Chinese).

Huang, J., R. Heyduck, R. Richins, D. VanLeeuwen, M.A. O'Connell, and S. Yao. 2017. Jujube cultivar vitamin C profile and nutrient dynamics during maturation. HortScience 52:859-867.

Liu, M. and M. Wang. 2009. Germplasm resources of Chinese jujube. China Forestry Publ. House, Beijing, China. (in Chinese).

Taylor, W.A. 1917. Inventory of seeds and plants imported by the Office of Foreign Seed and Plant Introduction during the period from 1 Jan. to 31 Mar. 1914. Inventory no. 38 . Nos: 36937 to 37646. 26 June 2018. <https://naldc. nal.usda.gov/naldc/download.xhtml? $\mathrm{id}=37033 \&$ content $=$ PDF $>$.
Thomas, C.C. 1927. Chinese jujube in southwestern United States, p. 212-215. In: USDA Yearbook of Agriculture 1926. 28 Apr. 2018. <http://naldc.nal.usda. gov/download/IND43842740/PDF>.

Thomson, P.H. 1971. Deciduous fruits for southern California, jujube. California Rare Fruit Grower Nwsl. 3(4):7.

Yao, S. 2018. Jujube phenology, pollen germination and two unique germplasm resources in New Mexico. HortScience 53:23-27.

Yao, S., J. Huang, and R. Heyduck. 2015. Jujube (Ziziphus jujuba Mill.) flowering and fruiting in the southwestern United States. HortScience 50:839-846.

Yao, S. 2013a. Past, present, and future of jujubes-Chinese dates in the United States. HortScience 48:672-680.

Yao, S. 2013b. Unique fruit development of ornamental 'Teapot' jujube. HortTechnology 23:364-368.

Zhao, Z., R. Richins, R. Heyduck, M.A. O'Connell, and S. Yao. 2017. cAMP distributing profiles of Chinese jujube in New Mexico State. HortScience 52(9): S350 (abstr.). 